\title{
Simultaneous Estimation of Pregabalin and Etoricoxib using Novel HPLC Method: An Application in Quantitative Analysis of Pharmaceutical Dosage Forms
}

\author{
Amit Chaudhary, Bhuvnesh Kumar Singh* \\ School of Pharmacy, Abhilashi University, Mandi, Himachal Pradesh, INDIA.
}

\begin{abstract}
Introduction: A new optimised method was developed for simultaneous estimation of new FDA approved drugs using RP-HPLC method that would emphasize the use of these drugs in various industries for quality measurements. Objectives: The objective of the present study to develop and validate a new simple, novel, precise, rapid, reliable, accurate and reproducible reverse-phase high-performance liquid chromatography (RPHPLC) technique for simultaneous estimation of Pregabalin (PREG) and Etoricoxib (ETOR) in bulk and formulation. Materials and Mehtods: This separation was done by using a mixture of methanol: acetonitrile: phosphate buffer $(\mathrm{pH} 5)$ at the ratio of $(40: 20: 20)$ as mobile phase, with a hypersil ODS, $C_{18}(250 \mathrm{~mm} \times 4.6 \mathrm{~mm}$, i.d.2.5 $\mu \mathrm{m})$. The flow rate was $1.0 \mathrm{ml} \mathrm{min}^{-1}$ and effluents were monitored at $215 \mathrm{~nm}$ by using UV-visible detector with injection volume was $20 \mu$ l. Results: They were found to be linear over a range of 12.5-37.5 $\mathrm{mg} \mathrm{ml}^{-1}$ and 150-450 $\mathrm{gg} \mathrm{m}^{-1}$ for PREG and ETOR respectively. The retention time of PREG and ETOR was $3.523 \mathrm{~min}$ and $4.702 \mathrm{~min}$, respectively. The mean percentage recoveries of PREG and ETOR were found to be $100.27 \%$ and $99.91 \%$, respectively. The LOD was found 1.89 and $2.26 \mathrm{\mu g} \mathrm{ml}^{-1}$ and the LOQ were found 5.73 and $6.84 \mathrm{\mu g} \mathrm{ml}^{-1}$, for PREG and ETOR, respectively. Conclusion: This novel validated economical methods could be applicable for analysis of PREG and ETOR in pharmaceutical industries.
\end{abstract}

Key words: Pregabalin, Etoricoxib, Method Validation, Simultaneous, ICH.

\section{INTRODUCTION}

Pregabalin (PREG) which is an anticonvulsant and antiepileptic drug, is used for neuropathic pain and as an addition therapy for partial seizures in adults. IUPAC name of Pregabalin is (3S)-3-(Aminomethyl)5 -methylhexanoic acid which shown in Figure $10^{1,2}$ It binding to the alpha2-delta subunit (voltage-gated calcium channels) may be involved for the anti-nociceptive and antiseizure effects of Pregabalin in animals. Etoricoxib (ETOR) is 5-chloro2-(6-methylpyridin-3-yl)-3-(4-methylsulfonylphenyl) pyridine represented with the help of Figure 2. It is a selective cyclo oxygenase 2 inhibitor with a non-steroidal and anti-inflammatory properties used in the treatment of rheumatoid arthritis, osteoarthritis and acute gouty arthritis with low GI toxicity and is without effects on platelet function. ${ }^{3-5}$ On detailed literature survey, it was found that ETOR in dosage form are spectrophotometry, RP-HPLC and similarly for the estimation of PREG in dosage form are spectrophotometry, HPTLC, RP-HPLC. . $^{6-12}$ Previously, some analytical methods for determining PREG individually or in combination with nortriptyline, tapentadol, amitriptyline, mecobalamin, and alpha lipoic acid were established. Since no
Submission Date: 22-12-2020; Revision Date: 03-03-2021; Accepted Date: 19-05-2021

DOI: 10.5530/ijper.55.3s.191 Correspondence:

Mr. Bhuvnesh Kumar Singh, Department of Pharmaceutical Analysis, School of Pharmacy, Abhilashi University,

Mandi- 175028, Himachal Pradesh, INDIA.

Phone: +917417423978 , Email-pharma0305@gmail. com

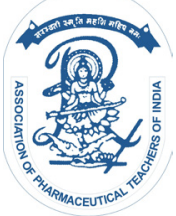

www.ijper.org 


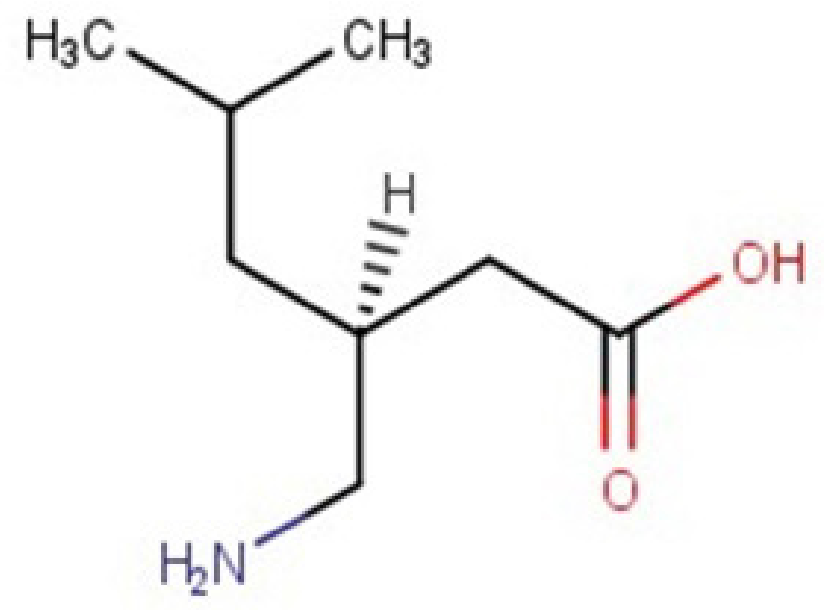

Figure 1: Structure of Pregabalin

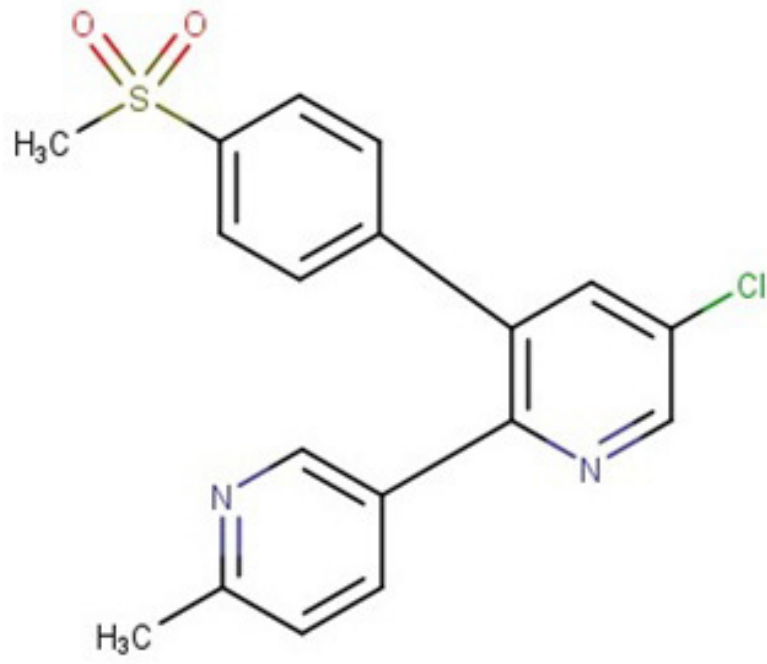

Figure 2: Structure of Etoricoxib

HPLC methods for simultaneous estimation of PREG and ETOR in a mixture of drugs have been published, the current study made an effective attempt to estimate both drugs using a simple, optimised, isocratic RP-HPLC method. ${ }^{13-17}$ The proposed method was developed and validated as per ICH guidelines ICH Q2 A and ICH Q2 B. ${ }^{18-20}$

\section{MATERIALS AND METHODS}

\section{Instrumental and analytical conditions}

For the simultaneous estimation of drugs with an isocratic HPLC $\left(\right.$ Shimadzu $\left.^{\circledR}\right)$ having two LC-20AD pumps, with adaptable wavelength programmable SPD-M20A photo diode array detector, CBM-20A system controller and LC solution software of Shimadzu ${ }^{\circledR}$ with the hypersil ODS- $C_{18}(250 \mathrm{~mm} \times 4.6 \mathrm{~mm}$, i.d.2.5 $\mu \mathrm{m})$ columns and wavelength $215 \mathrm{~nm}$ was used for detection. The run time of the sample was found to be $15 \mathrm{~min}$ of $20 \mu \mathrm{l}$ injection volume. The flow rate of an isocratic mobile phase was found to be $1 \mathrm{ml} \mathrm{ml}^{-1}$ which was consisted of methanol: acetonitrile: phosphate buffer $(\mathrm{pH} \mathrm{5})$ at the ratio of $(40: 20: 20)$ as membrane filter of $0.45 \mu \mathrm{m}$ porosity was used to filter the mobile phase was and same was degassed for further processing.

\section{Reagents and chemicals}

PRE and ETOR bulk drug was obtained from AKUMS drugs pharmaceutical Ltd, Haridwar, Uttrakhand, India as a gift sample. ETOSHINE ${ }^{\circledR}$ NP brand of Sun Pharmaceutical Industries Ltd was obtained from local pharmacy containing Pregabalin (75mg) and Etoricoxib (60mg). Methanol, acetonitrile served by Merck (India) Limited. All other chemicals included in the study were of AR grade. A Millipore and Milli-Q system was utilized to obtain filtration and ultrapure water.

\section{Preparation of Mobile Phase}

The mobile phase used in this study was composed of methanol: acetonitrile: phosphate buffer $(\mathrm{pH} 5)$ at the ratio of 40:20:20 v/v, with isocratic elution. Filtration was done by 0.45 -micron nylon membrane (Millipore) filter and an ultrasonic bath was used to degassed before further use to circumvent conflicts and clogging of the column due to small particles. Standard and sample preparations were achieved with methanol and acetonitrile as diluent. The mobile phase was screened based on system suitability.

\section{Preparation of Standard Solution}

The primary standard stock solution was prepared by dissolving $75 \mathrm{mg}$ PRE and $60 \mathrm{mg}$ ETOR in $100 \mathrm{ml}$ volumetric flask in $75 \mathrm{ml}$ in diluent and sonicated for $15 \mathrm{~min}$ with the help of sonicator for complete dissolve the drugs and after sonication volume make up $100 \mathrm{ml}$ with the same solvent. Take the volume of primary standard stock solution $(0.1,0.2,0.4,0.6,0.8$, 1.0, 1.2 and $1.4 \mathrm{ml}$ ) and make up to $10 \mathrm{ml}$ with diluent. The final concentration of PRE (10 to $105 \mu \mathrm{g} \mathrm{ml}^{-1}$ ) and ETOR (6 to $84 \mu \mathrm{g} \mathrm{m}^{-1}$ ) was used for the study purpose. The final solution was filtered through a $0.45 \mu$ nylon Millipore membrane filter.

\section{Preparation of Sample Solution}

20 tablets of Etoshine NP were accurately weighed and pulverized. The powder equivalent to $75 \mathrm{mg}$ PRE was weighed and then transferred into a clean and dried $100 \mathrm{ml}$ volumetric flask. The tablet powder was dissolved into the mobile phase (methanol: acetonitrile: 
phosphate buffer $(\mathrm{pH} \mathrm{5)}$ at the ratio of 40:20:20 v/v) using sonication and then the volume was made up to $100 \mathrm{ml}$ with same. Then it was filtered using $0.45 \mu$ filter and diluted to get 7.5 and $6.0 \mu \mathrm{g} \mathrm{ml}^{-1}$ of PRE and ETOR respectively. The $20 \mu \mathrm{l}$ of working sample was injected through hypersil ODS- $\mathrm{C}_{18}(250 \mathrm{~mm} \times 4.6$ $\mathrm{mm}$, i.d.2.5 $\mu \mathrm{m}$ ) column with the flow rate of $1 \mathrm{ml}$ $\min ^{-1}$ and the eluents were measured at $215 \mathrm{~nm}$.

\section{RESULTS AND DISCUSSION}

\section{Method Development}

The main objective of this study to develop and validate a simple, precise, reliable, rapid, more accurate, as well as least time-consuming High-Performance Liquid Chromatography (HPLC) method for simultaneous PRE and ETOR in API as well as in various formulations comply with ICH guideline. The method was optimized and validated by changing different parameter like mobile phase composition, $\mathrm{pH}$, elution technique, flow rate and appropriate columns to achieve sharp peak, maximum theoretical plates, less tailing factor and short analysis time. A typical chromatogram found by the same condition mentioned above illustrated in Figure 3. The system suitability test is of importance in the validation of analytical technique as well as confirmation of resolution amongst numerous peaks of the interest. All perilous parameters (theoretical plates, retention time and tailing factor) in the study met complete acceptance every time. \% RSD for peak area of six replicate was found to be 0.099 and 0.237 for PRE and ETOR respectively. \% RSD for retention time was found to be 1.23 and 1.14 for PRE and ETOR. Tailing factor was under 2 and theoretical plate more than 2000 show that the method was met under condition during the validation.

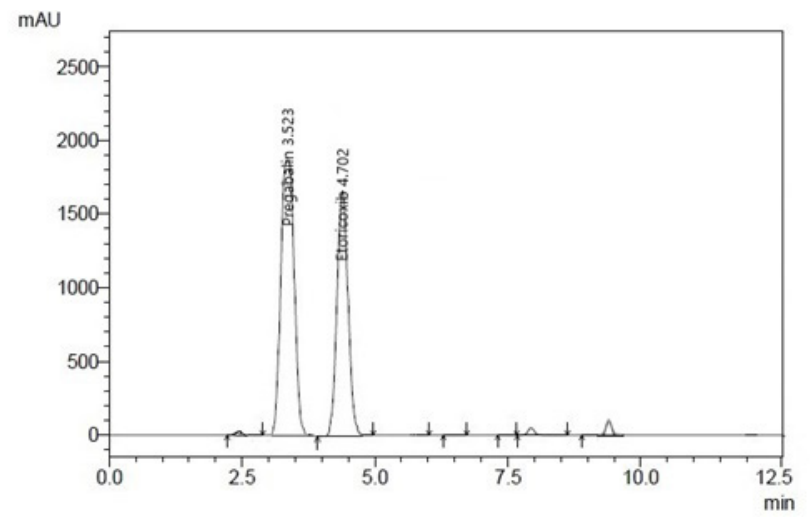

Figure 3: Chromatogram representing the separation of PRE and ETOR System suitability

\section{Method Validation}

\section{Specificity}

Good resolution and no interference from blank and excipients were observed that this method is specific for simultaneous analyzing of PRE and ETOR. The explanatory chromatogram did not show any other peak confirming to the specificity of this method.

\section{Stress (forced decomposition) studies on formulation}

In a $100 \mathrm{~mL}$ volumetric flask, a quantity of the powder equivalent to $75 \mathrm{mg}$ of PRE and $60 \mathrm{mg}$ of ETOR was transferred and added $40 \mathrm{~mL}$ of water, acid, base, and $\mathrm{H}_{2} \mathrm{O}_{2}$ solutions individually. The formulation was subjected to physico-chemical conditions in order to degrade $10 \%$ of the compound. The stressed samples were neutralised and diluted with mobile phase, then filtered through 0.45 filtered, sonicated for 10 minutes, and sufficiently diluted with mobile phase to have a final concentration of $7.5 \mu \mathrm{g} \mathrm{ml}^{-1} \mathrm{PRE}$ and $6 \mu \mathrm{g} \mathrm{ml}^{-1}$ ETOR. Since the drugs peak was well differentiated even in the presence of degradation products, this stabilityindicating approach for the determination of PRE and ETOR in tablet dosage form is unique. Overall, the data showed that the excipients and degradation products had no effect on the drug peak, suggesting that the process had the best selectivity. Based on the peak area shown in Figure 4, quantification was achieved using UV detection at $215 \mathrm{~nm}$. The main goal of developing the chromatographic method was to isolate the degradation products obtained from stress studies from the drug peak.

\section{Accuracy}

Then recovery was estimated at $50 \%, 100 \%$ and $150 \%$ of the selected concentrations. Three samples were prepared for each recovery level and recovery values for PRE and ETOR were found to be $99.53-101.70 \%$ and 99.70 to $101.29 \%$, respectively as described in Table 1 and Figure 5.

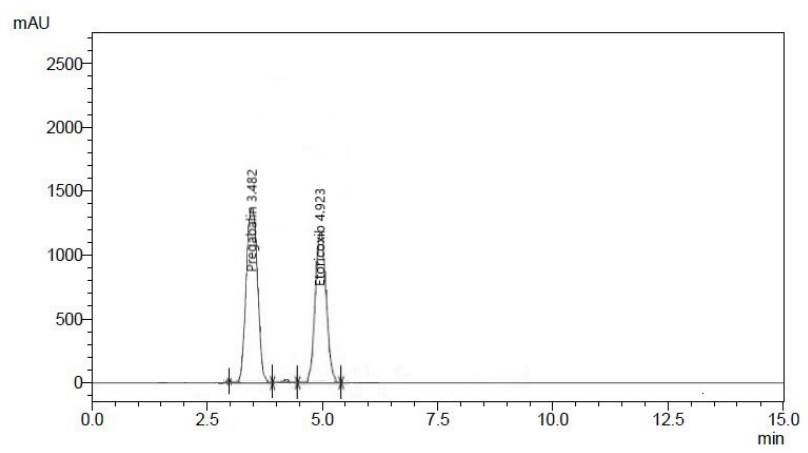

Figure 4: Chromatogram of acid degradation 


\begin{tabular}{|c|c|c|c|c|c|c|c|}
\hline $\begin{array}{c}\text { Name of the } \\
\text { drug }\end{array}$ & $\begin{array}{l}\text { Spiked } \\
\text { amount }\end{array}$ & $\begin{array}{l}\text { Amount of drug } \\
\text { (Tablet) } \mu g\end{array}$ & $\begin{array}{l}\text { Amount of drug } \\
\text { (Standard) } \mu \mathrm{g}\end{array}$ & Total Drug $(\mu \mathrm{g})$ & $\begin{array}{l}\text { Total Found }(\mu g) \\
\text { Mean } \pm \text { SD }\end{array}$ & \% RSD & \% Recovery \\
\hline \multirow[b]{3}{*}{ PRE } & $50 \%$ & 15 & 5 & 20 & $20.34 \pm 0.320$ & 1.58 & 101.70 \\
\hline & $100 \%$ & 15 & 10 & 25 & $25.16 \pm 0.336$ & 1.34 & 100.64 \\
\hline & $150 \%$ & 15 & 15 & 30 & $29.86 \pm 0.391$ & 1.31 & 99.54 \\
\hline \multirow[b]{3}{*}{ ETOR } & $50 \%$ & 12 & 5 & 17 & $17.22 \pm 0.164$ & 0.95 & 101.30 \\
\hline & $100 \%$ & 12 & 10 & 22 & $22.22 \pm 0.370$ & 1.67 & 101.00 \\
\hline & $150 \%$ & 12 & 15 & 27 & $26.92 \pm 0.443$ & 1.65 & 99.70 \\
\hline
\end{tabular}

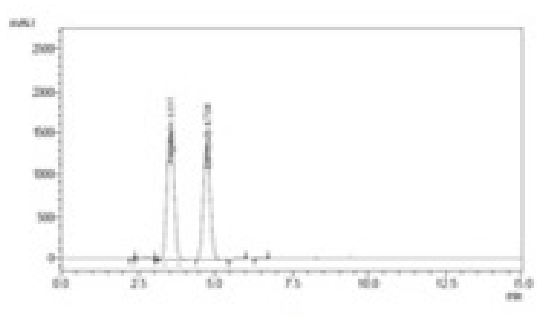

A

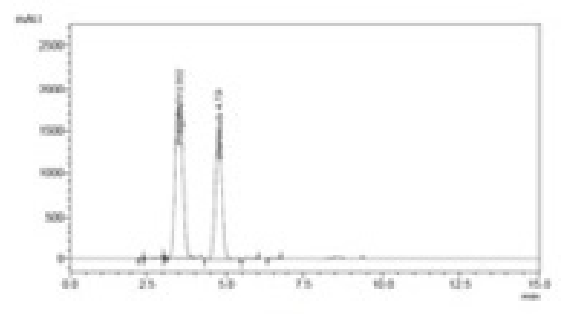

B

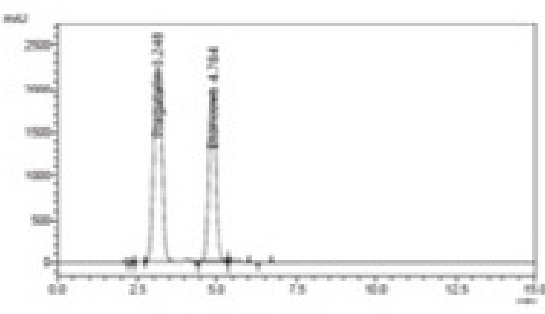

C

Figure 5: Accuracy study of PRE and ETOR at $50 \%$ (A), $100 \%$ (B), and $150 \%$ (C). Precision

\begin{tabular}{|c|c|c|c|c|}
\hline \multirow{3}{*}{$\begin{array}{l}\text { Injection } \\
\text { Number }\end{array}$} & \multicolumn{2}{|c|}{ System Precision } & \multicolumn{2}{|c|}{ Method Precision } \\
\hline & \multicolumn{2}{|c|}{ Peak areas } & \multicolumn{2}{|c|}{$\%$ Assay } \\
\hline & PRE & ETOR & PRE & ETOR \\
\hline 1 & 2245768 & 1945874 & 101.23 & 102.34 \\
\hline 2 & 2194854 & 1894873 & 99.34 & 99.27 \\
\hline 3 & 2189463 & 1934574 & 99.45 & 99.45 \\
\hline 4 & 2249463 & 1946286 & 100.45 & 100.35 \\
\hline 5 & 2276623 & 1967975 & 99.57 & 99.58 \\
\hline 6 & 2224523 & 1956783 & 101.45 & 101.45 \\
\hline Mean & 2230116 & 1941061 & 100.25 & 100.41 \\
\hline $\mathrm{SD}( \pm)$ & 33792.20 & 25288.00 & 0.93 & 1.25 \\
\hline RSD (\%) & 1.52 & 1.30 & 0.93 & 1.24 \\
\hline $\begin{array}{c}\text { Acceptance } \\
\text { criteria }\end{array}$ & \multicolumn{4}{|c|}{$\%$ RSD should not be more than 2} \\
\hline
\end{tabular}

For the precision study, overall \% RSD of system, method precision was found to less than 2 which indicate that the precision achieved successfully in the limit. The results are given in Table 2 .

\section{Intermediate precision (Ruggedness)}

Interday and interday fluctuations were achieved using six replicate injections of standard and sample solutions, those were prepared and analyzed by different analysts on three different days over one week. Ruggedness was also expressed in terms of percentage RSD and statistical analysis revealed no significant difference between obtained results retaining different analyst. Interday and interday precision \% RSD was found to be under significant value and showed in Table 3.

\section{Linearity and range}

The method for linearity was evaluated from the calibration curve data and the linear value was observed between range from 2.5- $105 \mu \mathrm{g} \mathrm{ml}^{-1}$ and 2.0- $94 \mu \mathrm{g} \mathrm{ml}^{-1}$ for PRE and ETOR respectively. During simultaneous determination, the calibration curves were linear and the correlation coefficients $(r 2)$ were found to be 0.999 for both drugs which are shown in Figure 6.

\section{Robustness}

The robustness of the analytical procedure was established and developed by changing of flow rate, $\mathrm{pH}$, wavelength and mobile phase composition. The robustness data of both drugs have been incorporated in Table 4 . 


\begin{tabular}{|c|c|c|c|c|}
\hline \multirow[b]{2}{*}{ Concentration } & \multicolumn{2}{|c|}{ Intraday Precision } & \multicolumn{2}{|c|}{$\begin{array}{c}\text { Interday Precision } \\
\text { (Day } 1,2,3)\end{array}$} \\
\hline & Area of PRE & Area of ETOR & Area of PRE & Area of ETOR \\
\hline \multirow{3}{*}{$\begin{array}{c}\text { PRE } 60\left(\mu \mathrm{g} \mathrm{ml}^{-1}\right) \text { and ETOR } \\
48\left(\mu \mathrm{g} \mathrm{ml}^{-1}\right)\end{array}$} & 1758302 & 1566838 & 1754632 & 1581836 \\
\hline & 1748457 & 1576385 & 1734653 & 1573330 \\
\hline & 1747658 & 1554392 & 1742382 & 1562364 \\
\hline Mean & 1751472.3 & 1565872 & 1743889 & 1572510 \\
\hline SD & 5928.14 & 11028.30 & 10074.39 & 9761.86 \\
\hline$\%$ RSD & 0.34 & 0.70 & 0.58 & 0.62 \\
\hline \multirow{3}{*}{$\begin{array}{c}\text { PRE } 75\left(\mu \mathrm{g} \mathrm{ml}^{-1}\right) \text { and } \mathrm{ETOR} \\
60\left(\mu \mathrm{g} \mathrm{ml}^{-1}\right)\end{array}$} & 2173254 & 1956233 & 2175284 & 2041483 \\
\hline & 2153728 & 1945732 & 2166345 & 1983747 \\
\hline & 2099463 & 1944599 & 2184735 & 1987743 \\
\hline Mean & 2142148.30 & 1948855 & 2175455 & 2004324.33 \\
\hline SD & 38234.07 & 6414.89 & 9196.19 & 32242.32 \\
\hline$\%$ RSD & 1.78 & 0.33 & 0.42 & 1.61 \\
\hline \multirow{3}{*}{$\begin{array}{c}\text { PRE } 90\left(\mu \mathrm{g} \mathrm{ml}^{-1}\right) \text { and ETOR } \\
72\left(\mu \mathrm{g} \mathrm{ml}^{-1}\right)\end{array}$} & 2637685 & 2347568 & 2597393 & 2297473 \\
\hline & 2695736 & 2394738 & 2603726 & 2347422 \\
\hline & 2637646 & 2374432 & 2589302 & 2337374 \\
\hline Mean & 2657022.30 & 2372246 & 2596807 & 2327423 \\
\hline SD & 33527.02 & 23660.86 & 7229.83 & 26419.55 \\
\hline$\%$ RSD & 1.26 & 1.00 & 0.28 & 1.14 \\
\hline
\end{tabular}
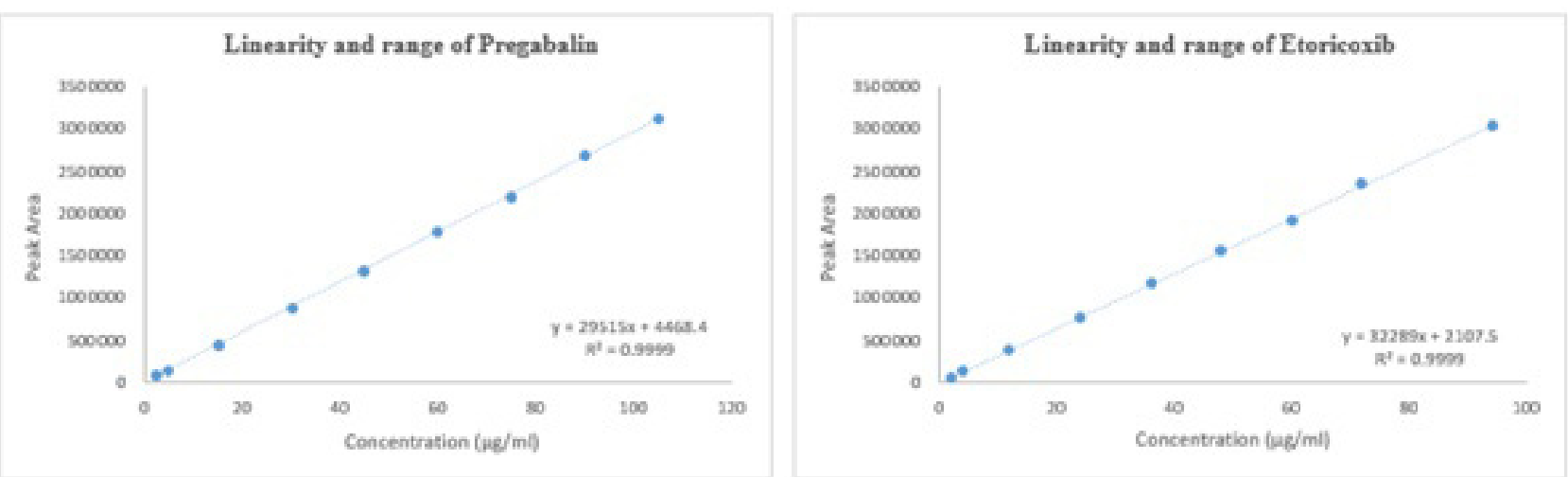

Figure 6: Linearity and range of PRE and ETOR

\section{Detection and quantitation limits}

The limit of detection and limit of quantitation were found to be 1.89, $5.73 \mu \mathrm{g} \mathrm{ml}^{-1}$ for PRE and 2.26, 6.84

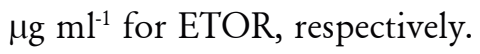

\section{Assay of tablets}

Currently, in the market, only one manufacturer brand name ETOSHINE ${ }^{\circledR}$ NP (Sun Pharmaceutical Industries
Ltd) available and its percentage assay was found to be $101.34 \%$ and $102.65 \%$ for PRE and ETOR, respectively.

\section{CONCLUSION}

A new RP-HPLC method was developed and validated for simultaneous estimation of PRE and ETOR in bulk and tablet dosage form. The proposed novel, fast, accurate and precise method was successfully applied in 


\begin{tabular}{|c|c|c|c|c|c|c|c|}
\hline \multirow[b]{2}{*}{ Condition } & & \multicolumn{3}{|c|}{ PRE } & \multicolumn{3}{|c|}{ ETOR } \\
\hline & & $\%$ RSD & $\begin{array}{l}\text { Tailing } \\
\text { Factor }\end{array}$ & $\%$ Recovery & \% RSD & $\begin{array}{l}\text { Tailing } \\
\text { Factor }\end{array}$ & $\begin{array}{c}\% \\
\text { Recovery }\end{array}$ \\
\hline \multirow{3}{*}{ Change in Flow rate } & $\begin{array}{l}\text { Normal Flow rate } \\
\text { (1.0 ml per minute) }\end{array}$ & 0.78 & 1.09 & 100.18 & 0.87 & 1.11 & 100.67 \\
\hline & $\begin{array}{l}\text { Change in flow rate } \\
\text { (0.8 ml per minute) }\end{array}$ & 0.89 & 1.11 & 98.57 & 0.91 & 1.14 & 100.89 \\
\hline & $\begin{array}{l}\text { Change in flow rate } \\
(1.2 \mathrm{ml} \text { per minute) }\end{array}$ & 0.78 & 1.02 & 99.45 & 0.78 & 1.32 & 100.56 \\
\hline \multirow{3}{*}{ Change in $\mathrm{pH}$} & Normal Condition (5.0) & 0.23 & 1.10 & 99.78 & 0.23 & 1.04 & 99.45 \\
\hline & Oven temperature $(4.5)$ & 0.45 & 1.23 & 100.98 & 0.47 & 1.21 & 100.12 \\
\hline & Oven temperature $(5.5)$ & 0.46 & 1.31 & 100.45 & 1.02 & 1.09 & 100.18 \\
\hline \multirow{3}{*}{$\begin{array}{c}\text { Change in Wave } \\
\text { Length }\end{array}$} & Normal: Wave Length $215 \mathrm{~nm}$ & 0.34 & 1.08 & 99.46 & 0.67 & 1.00 & 100.67 \\
\hline & Wave Length $210 \mathrm{~nm}$ & 0.56 & 1.10 & 101.78 & 0.78 & 1.15 & 100.45 \\
\hline & Wave Length 220nm & 0.67 & 1.31 & 98.99 & 0.23 & 1.35 & 100.18 \\
\hline \multirow{3}{*}{$\begin{array}{l}\text { Change composition } \\
\text { of mobile phase }\end{array}$} & $\begin{array}{l}\text { Normal Condition (Methanol: } \\
\text { ACN: Buffer) }(50: 20: 30)\end{array}$ & 0.18 & 1.02 & 99.18 & 0.45 & 1.19 & 101.11 \\
\hline & $\begin{array}{c}\text { (Methanol: ACN: Buffer) } \\
(40: 30: 30)\end{array}$ & 0.81 & 1.03 & 99.87 & 1.01 & 1.11 & 100.23 \\
\hline & $\begin{array}{c}\text { (Methanol: ACN: Buffer) } \\
(60: 10: 30)\end{array}$ & 0.64 & 1.31 & 99.46 & 0.34 & 1.26 & 99.89 \\
\hline
\end{tabular}

pharmaceutical industries for the routine quantitative analysis of new fixed-dose combinations approved by DCGI in December 2019.

\section{ACKNOWLEDGEMENT}

The authors would like to thank AKUMS drugs pharmaceutical Ltd, Haridwar, Uttrakhand, India for providing the gift samples.

\section{CONFLICT OF INTEREST}

The authors have no conflict of interests.

\section{ABBREVIATIONS}

PRE: Pregabalin; ETOR: Etoricoxib; ICH: International Council for Harmonisation; $\mu$ : Microliter; cm: Centimeter; HPLC: High-Pressure Liquid Chromatography; LOD: Limit of Detection; LOQ: Limit of Quantification; nm: Nanometer; SD: Standard Deviation.

\section{REFERENCES}

1. Sweetman SC, editor. Martindale: the complete drug reference. London: Pharmaceutical press; 2009 Jun 29
2. Vyas AJ, Nathwani GP, Patel AI, Patel NK, Patel AB. Validated Stability Indicating RP-HPLC DAD Method for Simultaneous Determination of amitriptyline hydrochloride and pregabalin in Presence of Stress degradation products in tablet dosage form. Chem Methodol. 2019 Jul 1;3(4):494-508.

3. Vhanmane A, Tamboli A, More S. RP-HPLC method development and validation for the simultaneous estimation of gabapentin and amitriptyline hydrochloride in pharmaceutical dosage forms. J Drug Deliv Ther. 2019 Jun 15;9(3-s):62-8.

4. Alzweiri M, Sallam M, Al-Zyoud W, Aiedeh K. Stability study of etoricoxib a selective cyclooxygenase-2 inhibitor by a new single and rapid reversed phase HPLC method. Symmetry. 2018 Jul;10(7):288. doi: 10.3390/ sym10070288.

5. Parameswari SA, Arunamma G. Stability indicating RP-HPLC method for simultaneous determination of epalrestat and pregabalin in bulk and tablet dosage form. Int J Pharm Sci Res. 2018 May 1;9(5):1844-50.

6. Shahi SR, Agrawal GR, Rathi PB, Shinde NV, Somani VG, Mahamuni SB, Padalkar AN. Development and validation of UV spectrophotometric method for the determination of etoricoxib in bulk and tablet formulation. Rasayan $\mathrm{J}$ Chem. 2008;1(2):390-4.

7. Singh S, Mishra A, Verma A, Ghosh AK, Mishra AK. A simple ultraviolet spectrophotometric method for the determination of etoricoxib in dosage formulations. J Adv Pharm Technol Res. 2012 Oct;3(4):237-40. doi: 10.4103/2231-4040.104715, PMID 23378945.

8. Shah NJ, Shah SJ, Patel DM, Patel NM. Development and validation of HPTLC method for the estimation of etoricoxib. Indian J Pharm Sci. 2006;68(6):788. doi: 10.4103/0250-474X.31016.

9. Dhaneshwar SR, Raut KO, Bhusari VK. Validated HPTLC method for simultaneous estimation of paracetamol and etoricoxib in bulk drug and formulation. Asian J Pharm Biol Res (AJPBR). 2011 Jun 1;1(2).

10. Gujral RS, Haque SM, Shanker P. Development and validation of pregabalin in bulk, pharmaceutical formulations and in human urine samples by UV spectrophotometry. Int J Biomed Sci. 2009 Jun;5(2):175-80. PMID 23675132. 
11. Pawar PY, Zanje LS, Tambe SS, Nandgaonkar AU, Funde PV, Vyavhare AA. Simultaneous estimation of pregabalin and paracetamol by UV spectroscopic method in bulk and tablet formulation. World J Pharm Pharm Sci (WJPPS). 2014;3(4):762-80.

12. Naguib IA, Ali NA, Elroby FA, El Ghobashy MR, Abdallah FF. Ecologically evaluated and FDA-validated HPTLC method for assay of pregabalin and tramadol in human biological fluids. Biomed Chromatogr. $2021 \mathrm{Nov}$ 9;35(4):e5023. doi: 10.1002/bmc.5023, PMID 33169415.

13. Chandra R, Sanghi A, Kumar D, Hindwan KK. Develop a simple RP-HPLC and UV-visible method for estimation of etoricoxib from pharmaceutical dosage. Br Biomed Bull. 2014;2(4):706-13.

14. Kumar S, Joshi A, Thakur RS, Pathak AK, Shah K. Simultaneous estimation of etoricoxib and thiocolchicoside by RP-HPLC method in combined dosage forms. Acta Pol Pharm. 2011 Nov 1;68(6):839-43. PMID 22125947.

15. Topalli S, Chandrashekhar TG, Annapurna MM. Validated RP-HPLC method for the assay of etoricoxib (a non-steroidal anti-inflammatory drug) in pharmaceutical dosage forms. E-Journal of Chemistry. 2012 Apr 1;9(2):832-8. doi: 10.1155/2012/264567.
16. Baheti KG, Shaikh S. Stability indicating RP-HPLC Method for Simultaneous Estimation paracetamol and Etoricoxib in Tablet formulation. Int J PharmTech Res. 2011;3(3).

17. Patel HM, Suhagia BN, Shah SA, Rathod IS. Determination of Etoricoxib in pharmaceutical formulations by HPLC method. Indian J Pharm Sci. 2007;69(5):703. doi: 10.4103/0250-474X.38485.

18. Potluri $H$, Battula SR, Yeturu S. Validated stability indicating RP-HPLC method for simultaneous determination of nortriptyline and pregabalin in bulk and combined dosage formulations. J Chil Chem Soc. 2017 Jun;62(2):3490-5. doi: 10.4067/S0717-97072017000200013.

19. Merugu M, Gumpula S, Sarigomula P. RP-HPLC method for simultaneous estimation of pregabalin and tapentadol in bulk and pharmaceutical dosage form. Asian J Biomed Pharm Sci. 2014 Sep 1;4(36):63.

20. Mohan AJ, Raj Kumar B, Bhavya T, Ashok Kumar A. RP-HPLC Method Development and validation for the simultaneous quantitative estimation of pregabalin, mecobalamin and alpha lipoic Acid in capsules. Int J Pharm Pharm Sci. 2014;6:270.

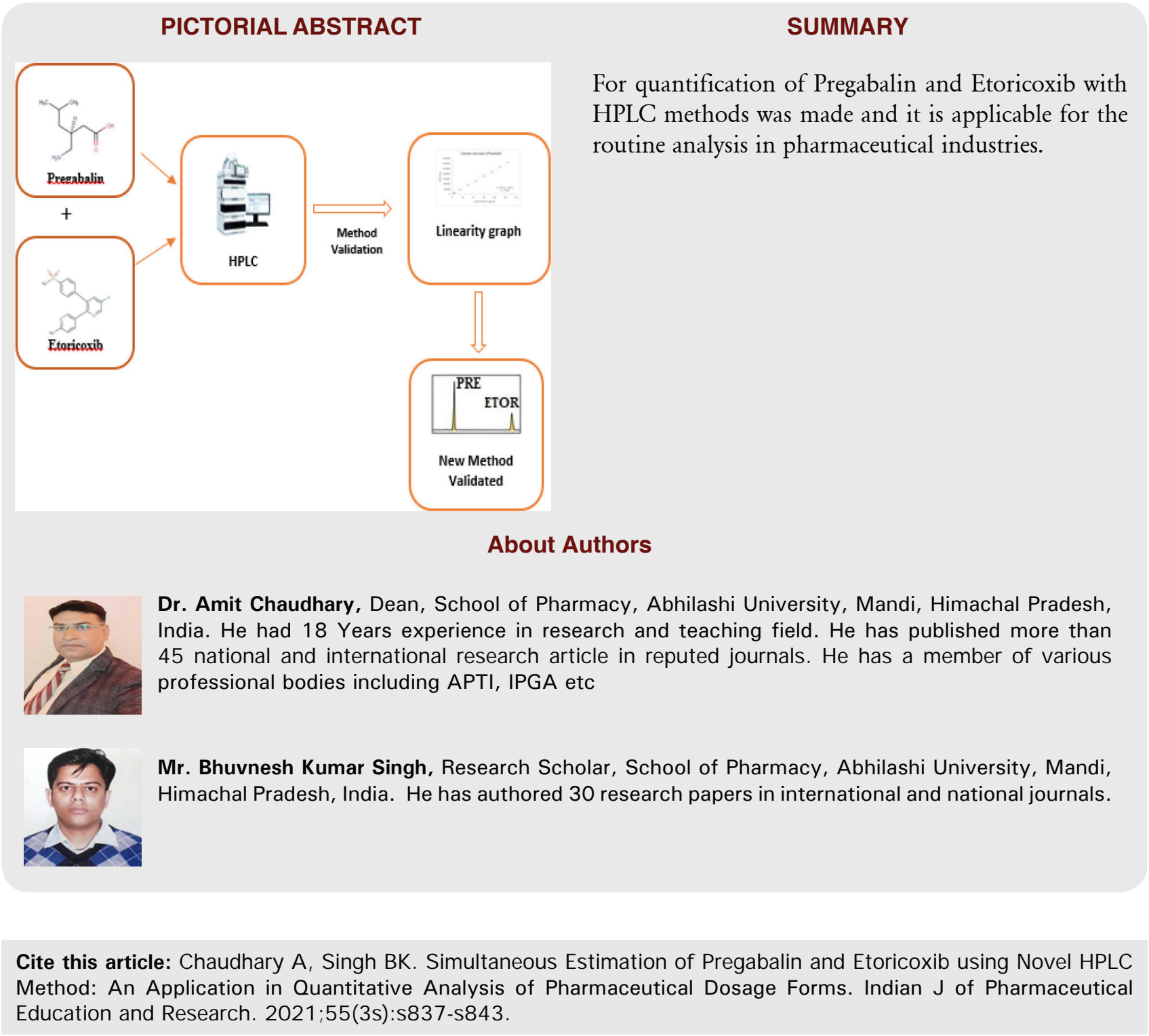

